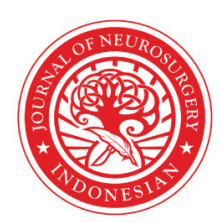

\title{
Inflammatory myofibroblastic tumor of the pituitary: A case report
}

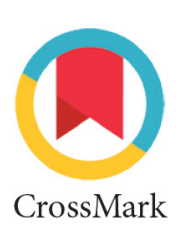

\author{
Saurabh Sharma ${ }^{1 *}$, Laila Sivanandapanicker Jyothish', Raja Kutty ${ }^{1}$, \\ Anil Kumar Peethambaran ${ }^{1}$, Milesh Nagar ${ }^{1}$, Sourabh Jain ${ }^{1}$
}

\section{ABSTRACT}

Introduction: Inflammatory myofibroblastic tumor (IMT), a subtype of inflammatory pseudotumor, is a rare cause of nonneoplastic sellar mass. IMTs have been reported in various anatomical locations of the body, but their presence in the Central Nervous System (CNS), especially in the pituitary gland, is rare. The objective of our case report is to analyze the basis of their mimicry, discuss their differential diagnosis, and review the literature related to inflammatory pseudotumors of the pituitary.

Case presentation: A 45-year-old male presented in our hospital with chief complaints of severe headache since two months ago and blurring of vision since two weeks ago. On investigation, Magnetic Resonance Imaging (MRI) revealed a pituitary macroadenoma, which was compressing the optic chiasma and encasing the left internal carotid artery. The patient underwent endonasal endoscopic transsphenoidal excision of the pituitary lesion and

became asymptomatic in the postoperative period. Histopathology reported the presence of spindle-shaped cells, inflammatory cells, respiratory epithelium lined tissue, and areas of necrosis suggestive of an inflammatory myofibroblastic tumor.

Conclusion: In the following communication, we discuss this esoteric pseudotumor of the pituitary and its peculiarities in diagnosis and management as it can easily disguise itself as a pituitary macroadenoma on radiological investigations, thus hoodwinking the physician of its actual pathology. We also review the literature to perceive the best management protocols and prognostic factors by drawing parallels with IMT in other parts of the CNS. The differential diagnosis of inflammatory myofibroblastic tumors of the CNS is difficult and relies mainly on histological analysis.
'Department of Neurosurgery, Trivandrum Medical College, Trivandrum, Kerala, India
*Corresponding author: Sharma S; Department of Neurosurgery, Trivandrum Medical College, Trivandrum, Kerala, India; ashu20030000@gmail.com
Received: 2019-08-04

Accepted: 2020-02-13

Published: 2020-04-09

Keywords: Inflammatory myofibroblastic tumor, pituitary neoplasm, plasma cell granuloma, pseudotumor

Cite This Article: Sharma, S., Jyothish, L.S., Kutty, R., Peethambaran, A.K., Nagar, M., Jain, S. 2020. Inflammatory myofibroblastic tumor of the pituitary: A case report. Indonesian Journal of Neurosurgery 3(1): 24-28. D0I: 10.15562/ijn.v3i1.77

\section{INTRODUCTION}

Inflammatory Myofibroblastic Tumors of Central Nervous System (IMT-CNS), have been reported in literature sporadically over the last few decades, but their presence in the pituitary gland was first reported in 2001. Although the pulmonary system is the most frequently involved site, the CNS, gastrointestinal tract, tonsils, urogenital tract, heart, and orbit may also be affected. Concomitant involvement, such as that of the lung and CNS, might be encountered as well. Only a few cases of Inflammatory Myofibroblastic Tumors of the pituitary gland (IMT-Sella) have been reported.

We discuss a case of pituitary IMT that mimicked pituitary macroadenoma but was later diagnosed on histopathology. The objective of our case report is to analyze the basis of their mimicry, discuss their differential diagnosis and review the literature for their behaviour, management protocols and prognosis by searching PubMed using the keywords such as "inflammatory myofibroblastic tumor", "plasma cell granuloma”, “inflammatory pseudotumor", "pituitary" and references cited in identified PubMed articles.

\section{CASE PRESENTATION}

A 45-year-old male presented with complaints of moderate to severe intensity, bifrontal headache for two months and blurring of vision in the temporal side of visual filed since two weeks ago. Neurological examination revealed bitemporal hemianopsia. His blood work was suggestive of panhypopituitarism. The patient was evaluated radiologically, and MRI revealed a large well defined $\mathrm{T} 1$ hyperintense lesion involving sella extending to the suprasellar region. The lesion measured $2 \times 2.1 \times 1.6 \mathrm{~cm}$. It appeared hyperintense in T1W1 and hyperintense in STIR with small hypointense areas. The lesion had multiple CSF signal intensity areas suggestive of cystic change. The T2W1 lesion had well defined peripheral hyperintense rim. The lesion extended into the suprasellar region. The optic chiasm appeared compressed by the mass lesion. Laterally, on the left side of the lesion was seen encasing the 


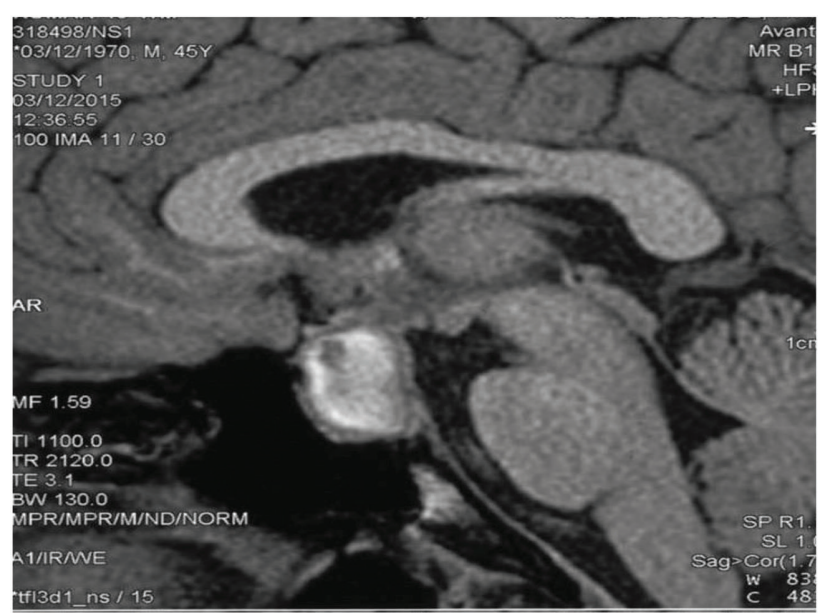

Figure 1. Brain MRI. Sagittal view showing hyperintense lesion on T1 image extending into the suprasellar region and compressing optic chiasm.

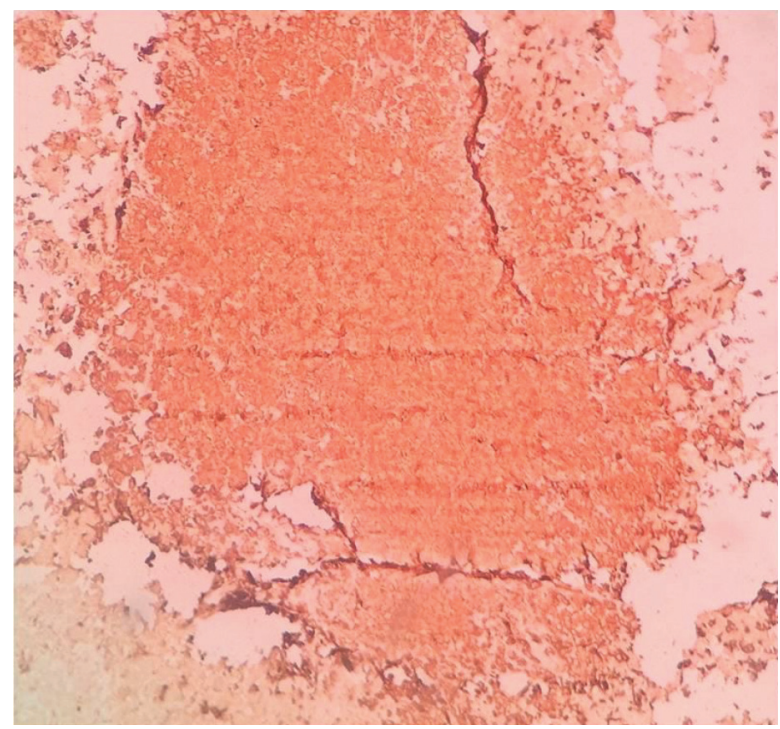

Figure 3. Immunohistochemistry showing Vimentin positivity.

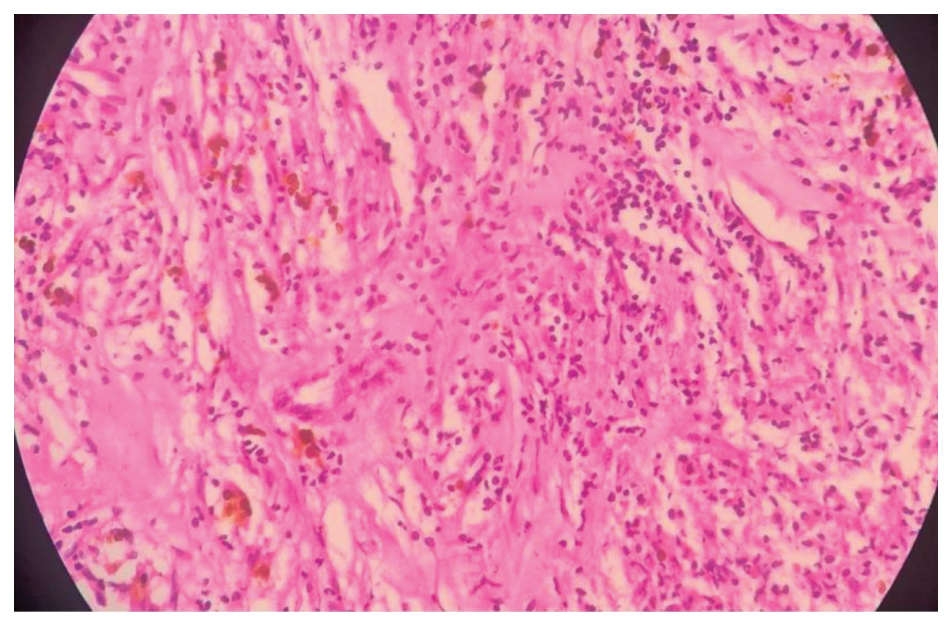

Figure 2. Microscopy showing spindle cells with moderate cytoplasm and elongated nuclei.

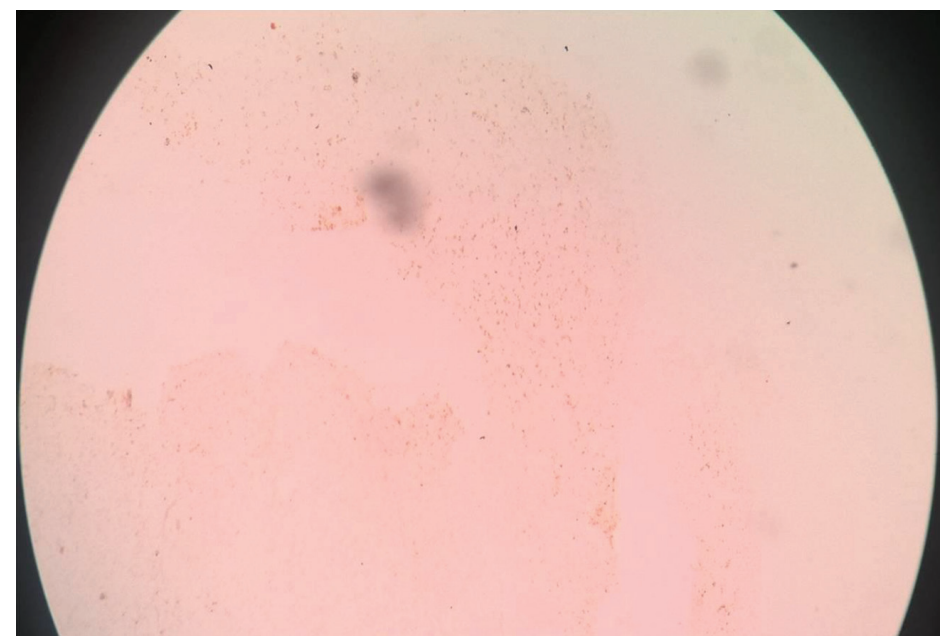

Figure 4. Immunohistochemistry negative for ALK. internal carotid artery (Figure 1).

A working diagnosis of pituitary adenoma was made, and the patient was taken up for endonasal endoscopic transsphenoidal total excision of pituitary adenoma. Intraoperatively, the tumor was firm to hard in consistency, grey-white in color and moderately vascular. In the post-op period, there were no complications such as CSF leak, bleeding, diabetes insipidus, and neurological deficit. It was uneventful, and the patient was relieved of his symptoms.

The histopathology revealed neoplasm composed of spindle-shaped cells arranged in short bundles. Individual cells were found to be spindly with a moderate amount of eosinophilic cytoplasm and elongated nuclei with tapered edges. Sprinkled in between these were epithelioid cells and lymphocytes. RBC's along with hemosiderinladen macrophages, respiratory epithelium lined tissue, and few areas of necrosis were also noted (Figure 2).

Immunohistochemistry of spindle cells was positive for Smooth Muscle Actin (SMA), Vimentin, negative for Anaplastic Lymphoma Kinase (ALK), CD1(a) and S100 (Figure 3 and 4).

Histological diagnosis of IMT was made. On discharge, the patient was given a course of corticosteroids. Six months post-surgery, repeat MRI revealed no residual/recurrent tumor. 


\section{DISCUSSION}

IMT is an arcane inflammatory pseudotumor first described by Bahadori and Leibow in 1973. ${ }^{1}$ Eventually it was found to be ubiquitous occurring commonly in the lung, omentum, mesentery and urinary bladder of children and young adults. ${ }^{2}$ IMT-CNS is a rare entity, with only 100 cases being reported so far. ${ }^{3}$ Most tumors arise from meningeal structures, though intracerebral and intraventricular lesions have been known to occur. ${ }^{4}$ From our literature search, only 7 cases of intrasellar IMT have been reported until now (Table 1). ${ }^{5-11}$

The scarcity of literature available on intrasellar IMT compelled us to extrapolate data from the cases, occurring in other areas of the central nervous system. Average age, median age and age range of IMT-CNS varies in different reports but that of IMT-Sella is found to be 44.8 years, 36 years and $18-62$ years respectively. No gender predominance was seen in our review for IMT-Sella, which is incongruent with a male predominance of IMTCNS. ${ }^{12}$ (Table 2)

Etiopathogenesis of IMT remains unascertained with the ongoing debate between infective and autoimmune pathology. Clinically, IMTSella presents with features of headache, vision problems and hypopituitarism. Differential diagnoses of pituitary IMT are pituitary adenomas, inflammatory and granulomatous lesions of pituitary, meningioma and lymphomas. Radiologically, IMT-Sella appears hyperattenuated

Table 1. Summary of cases of inflammatory myofibroblastic tumors of the pituitary in the literature

\begin{tabular}{|c|c|c|c|c|c|c|}
\hline Study & Sex/Age & Complaints & Therapy & Histology & Follow up & Outcome \\
\hline $\begin{array}{l}\text { Hansen et al. }{ }^{6} \\
(2001)\end{array}$ & $\mathrm{F} / 40$ & $\begin{array}{l}\text { Headache, left-sided } \\
\text { loss of vision, secondary } \\
\text { amenorrhea, asthenia }\end{array}$ & $\begin{array}{l}\text { Biopsy }+ \\
\text { corticosteroids }+ \\
\text { azathioprine }+ \\
\text { methotrexate }\end{array}$ & $\begin{array}{l}\text { No type } \\
\text { predominance } \\
\text { indicated }\end{array}$ & $\begin{array}{l}2 \text { years and } \\
6 \text { months }\end{array}$ & $\begin{array}{l}1^{\text {st }} \text { recurrence } \\
\text { on } 16 \text { months, } \\
2^{\text {nd }} \text { recurrence } \\
\text { on } 25 \text { months, } \\
\text { asymptomatic at the } \\
\text { end of } 2.5 \text { years. }\end{array}$ \\
\hline $\begin{array}{l}\text { Murakami et } \\
\text { al. }^{7}(2001)\end{array}$ & $\mathrm{F} / 34$ & Left-sided ptosis & Total gross resection & PCG & $\mathrm{NM}$ & $\begin{array}{l}\text { Uneventful } \\
\text { postoperative period }\end{array}$ \\
\hline $\begin{array}{l}\text { Al-Shraim et } \\
\text { al. }^{5}(2004)\end{array}$ & $M / 32$ & $\begin{array}{l}\text { Polyuria, polydipsia, } \\
\text { anorexia }\end{array}$ & $\begin{array}{l}\text { Total gross resection }+ \\
\text { corticosteroids }\end{array}$ & FHC & NM & $\begin{array}{l}\text { Patient responded } \\
\text { well }\end{array}$ \\
\hline $\begin{array}{l}\text { Jochum et al. } \\
\text { (2004) }\end{array}$ & $\mathrm{F} / 19$ & $\begin{array}{l}\text { Headache, secondary } \\
\text { amenorrhea }\end{array}$ & $\begin{array}{l}\text { Biopsy + partial } \\
\text { resection + stereotactic } \\
\text { radiotherapy }\end{array}$ & FHC & NM & $\begin{array}{l}\text { Tumor size kept } \\
\text { increasing }\end{array}$ \\
\hline $\begin{array}{l}\text { Yamagami et } \\
\text { al. }^{10}(2008)\end{array}$ & $\mathrm{M} / 18$ & $\begin{array}{l}\text { Headache, nasal } \\
\text { discharge, polyuria, } \\
\text { polydipsia, short stature }\end{array}$ & Biopsy + corticosteroids & FHC & 2 months & $\begin{array}{l}\text { Headache and nasal } \\
\text { discharge improved, } \\
\text { no improvement in } \\
\text { pituitary dysfunction }\end{array}$ \\
\hline $\begin{array}{l}\text { Kim et al. }{ }^{9} \\
(2011)\end{array}$ & $\mathrm{M} / 38$ & $\begin{array}{l}\text { Anorexia, sexual } \\
\text { dysfunction, } \\
\text { ophthalmoplegia, } \\
\text { diplopia }\end{array}$ & $\begin{array}{l}\text { Partial resection }+ \\
\text { corticosteroids }\end{array}$ & FHC & 3 years & $\begin{array}{l}\text { MRI showed } \\
\text { shrinkage of sellar } \\
\text { mass }\end{array}$ \\
\hline $\begin{array}{l}\text { Gautam et al. }{ }^{11} \\
(2017)\end{array}$ & $\mathrm{F} / 62$ & $\begin{array}{l}\text { Right focal motor } \\
\text { seizures }\end{array}$ & Total gross resection & $\mathrm{NM}$ & 1 year & $\begin{array}{l}\text { No residual } \\
\text { or recurrent } \\
\text { tumor, patient } \\
\text { asymptomatic }\end{array}$ \\
\hline $\begin{array}{l}\text { Present study } \\
(2016)\end{array}$ & $\mathrm{M} / 45$ & $\begin{array}{l}\text { Headache, blurred } \\
\text { vision }\end{array}$ & $\begin{array}{l}\text { Total gross resection }+ \\
\text { corticosteroids }\end{array}$ & FHC & 1 year & $\begin{array}{l}\text { No residual } \\
\text { or recurrent } \\
\text { tumor, patient } \\
\text { asymptomatic }\end{array}$ \\
\hline
\end{tabular}


on $\mathrm{CT}$ and homogenous hypointense lesions on T2 weighted images because of the lack of mobile protons in the fibrotic background. ${ }^{9}$

On histopathology, IMT is a unique lesion composed of myofibroblastic spindle cells accompanied by inflammatory cells. ${ }^{15}$ IMTs were classified into three histological patterns by Coffin et al. based on pulmonary and extra-pulmonary location. ${ }^{2}$ However, a classification relevant to IMT-CNS was proposed by Jeon et al. in 2005 . They described a two-tiered classification system of Plasma Cell Granuloma (PCG) variant and fibrohistiocytic (FHC) variant. ${ }^{12}$ The FHC variant is characterized by myofibroblastic proliferation with slight inflammatory cell component and the PCG like variant is the exact opposite, with distinct inflammatory cell component and limited myofibroblastic proliferation. In their study, Jeon et al. noticed, both variants presented equally, though in our review, FHC variant was predominant (Table 1). This clearly highlights the histopathological differences between the two entities, though its impact on disease progression cannot be stated,

Table 2. Demographic data of inflammatory myofibroblastic tumors of CNS and sella, as mentioned in literature.

\begin{tabular}{lcccc}
\hline \multicolumn{1}{c}{ Study } & $\begin{array}{c}\text { Average } \\
\text { age (years) }\end{array}$ & $\begin{array}{c}\text { Median age } \\
\text { (years) }\end{array}$ & $\begin{array}{c}\text { Range } \\
\text { (years) }\end{array}$ & $\begin{array}{c}\text { Sex ratio } \\
\text { (M:F) }\end{array}$ \\
\hline & IMT-CNS & & $11: 8$ \\
\hline $\begin{array}{l}\text { Greiner et al. }{ }^{13} \\
(2003)\end{array}$ & 34.1 & - & - & $7: 3$ \\
$\begin{array}{l}\text { Buccolieri et al. }{ }^{14} \\
(2003)\end{array}$ & - & 32 & $5-76$ & $3: 2$ \\
\hline Jeon et al. ${ }^{12}(2005)$ & 43.7 & 42.5 & $24-65$ & $1: 1$ \\
\hline
\end{tabular}

without carrying out further long term studies.

Immunohistochemically, these tumors are positive for SMA, muscle-specific actin, vimentin in up to $90 \%$ cases, desmin in up to $70 \%$ cases and negative for myogenin, S100 and Homatropine Methylbromide 45 (HMB45). In situ hybridization of FHC variant may often show clonal rearrangement in chromosome 2p23 leading to activation of the ALK gene. It has been reported that those IMTCNS, which express ALK, have an aggressive course and are associated with high recurrence rates. ${ }^{16}$

Treatment modalities considered for IMTCNS are surgical resection, corticosteroid therapy, radiotherapy and immunosuppressive therapy with ALK inhibitors. Treatment patterns mentioned in the literature and the present review are elaborated in Table 3. According to all of these studies, total surgical excision if achieved without much morbidity is the best modality. Corticosteroid therapy can be considered to avoid considerable surgical risk, especially in PCG like variants, which respond better to corticosteroid therapy than FHC variants. ${ }^{6}$

One recurrence and no cases of malignant transformation were noted in our study, although the average follow-up time was just 20 months, and maximum follow-up was carried out only for 3 years. Recurrence rates of $12.5 \%$ to $40 \%$ in IMT-CNS cases have been noted in the literature. ${ }^{17}$ (Table 3)

Gallago et al. studied all cases of recurrence in IMT-CNS and found 19 such instances in over 100 cases reviewed. ${ }^{3}$ Going through their data, we noted that the PCG variants had higher chances of recurrence than the FHC variants, and 11 out of 19 (57.8\%) patients were females. Twelve of the cases (63\%) who showed recurrence had not undergone gross total resection as their primary modality of management. The average time until recurrence for

Table 3. Various treatment patterns and recurrence rates in inflammatory myofibroblastic tumors of CNS as described in the literature.

\begin{tabular}{lccccccc}
\hline \multicolumn{1}{c}{ Study } & TGR (\%) & $\begin{array}{c}\text { STR } \\
(\%)\end{array}$ & $\begin{array}{c}\text { Biopsy } \\
(\%)\end{array}$ & $\begin{array}{c}\text { Irradiation } \\
(+/ \text { - surgery) } \\
(\%)\end{array}$ & $\begin{array}{c}\text { Corticosteroids } \\
(+/ \text { - surgery) } \\
(\%)\end{array}$ & $\begin{array}{c}\text { Chemotherapy } \\
\text { (+/- surgery) (\%) }\end{array}$ & $\begin{array}{c}\text { Recurrence } \\
\text { rates (\%) }\end{array}$ \\
\hline Hausler et al. ${ }^{4}(2003)(\mathrm{n}=43)$ & 65 & 25.5 & 37 & 30 & 25.5 & 0 & 25.5 \\
Greiner et al. ${ }^{13}(2003)(\mathrm{n}=38)$ & 60.5 & 24 & 16 & 24 & 0 & 0 & - \\
Jeon et al. ${ }^{12}(2005)(\mathrm{n}=10)$ & 60 & 30 & 10 & 10 & 10 & 0 & 12.5 \\
Present review $(\mathrm{n}=8)$ & 50 & 12.5 & 37.5 & 12.5 & 62.5 & 12.5 \\
\hline
\end{tabular}

TGR: Total gross resection; STR: Stereotactic radiotherapy 
patients who underwent complete resection was 37 months, while the average time until progression/ recurrence for the rest of the cases was 29 months. Hausler et al. also noted that the female gender and incomplete resection were independent risk factors for recurrence. ${ }^{4}$ Similarly, in our review, the only recurrence noted was in a female patient with incomplete resection. ${ }^{6}$

\section{CONCLUSION}

IMT-Sella is a rare neoplasm at a rare location. Histopathologically, these are FHC variant predominant lesions as compared to other CNS locations. Total surgical resection should be the target goals for treatment of all IMT. In case of difficult surgical access and contraindication to surgical procedures, treatment with corticosteroids can bring good results. The presence of PCG variant, female gender and incomplete resection are poor prognostic factors. It is important to differentiate the histopathological variant, so an early assessment can be made regarding the aggressiveness and malignant potential of the tumor and appropriate further management.

\section{FUNDING}

No funding accepted.

\section{CONFLICT OF INTEREST}

No conflicts of interest arose.

\section{AUTHORS' CONTRIBUTIONS}

Sharma $S$ is the corresponding author and was in charge of reviewing and editing the manuscript. Jyothish LS, Kutty R, and Peethambaran AK did the conception of the idea, reviewed and edited the manuscript. Nagar $M$ and Jain $S$ performed the literature search, reviewed and edited the manuscript.

\section{REFERENCES:}

1. Bahadori M, Liebow AA. Plasma cell granulomas of the lung. Cancer. 1973; 31(1): 191 - 208. DOI: $\quad 10.1002 / 1097-0142(197301) 31: 1<191:: a i d-$ cncr2820310127>3.0.co;2-d.

2. Coffin CM, Watterson J, Priest JR, Dehner LP. Extrapulmonary inflammatory myofibroblastic tumor (inflammatory pseudotumor). A clinicopathologic and immunohistochemical study of 84 cases. Am J Surg Pathol. 1995; 19(8): 859 - 72. DOI: 10.1097/00000478-19950800000001.

3. Pascual-Gallego M, Yus-Fuertes M, Jorquera M, GonzalezMate A, Ortega L, Martinez-Martinez A, et al. Recurrent meningeal inflammatory myofibroblastic tumor: A case report and literature review. Neurol India. 2013; 61(6): 644 - 9. DOI: $10.4103 / 0028-3886.125273$.
4. Hausler M, Schaade L, Ramaekers VT, Doenges M, Heimann G, Sellhaus B. Inflammatory pseudotumors of the central nervous system: Report of 3 cases and literature review. Hum Pathol. 2003; 34(3): 253 - 62. DOI: 10.1053/ hupa.2003.35.

5. Al-Shraim M, Syro LV, Kovacs K, Estrada H, Uribe H, AlGahtany M. Inflammatory pseudotumor of the pituitary: Case report. Surg Neurol. 2004; 62(3): 264 - 7. DOI: 10.1016/j.surneu.2003.09.037.

6. Hansen I, Petrossians P, Thiry A, Flandroy P, Gaillard RC, Kovacs K, et al. Extensive inflmmatory pseudotumor of the pituitary. J Clin Endocrinol Metab. 2001; 86(10): 4603 - 10. DOI: $10.1210 /$ jcem.86.10.7954.

7. Murakami K, Muraishi K, Ikeda H, Yoshimoto T. Plasma cell granuloma of the pituitary gland. Case report. Surg Neurol. 2001; 56(4): 247 - 51. DOI: 10.1016/s00903019(01)00599-7.

8. Jochum W, Hanggi D, Bruder E, Jeck T, Novotny H, Probst A, et al. Inflammatory myofibroblastic tumour of the sella turcica. Neuropathol Appl Neurobiol. 2004; 30(6): 692 - 5. DOI: 10.1111/j.1365-2990.2004.00611.x.

9. Kim DM, Yu IK, Kim HK, Son HJ. Inflammatory pseudotumor of the pituitary gland mimicking a pituitary adenoma: A case report. J Korean Soc Radiol. 2011; 64: 303 -7 .

10. Yamagami $\mathrm{K}$, Yoshioka $\mathrm{K}$, Isaka $\mathrm{Y}$, Inoue $\mathrm{T}$, Hosoi $\mathrm{M}$, Shakudo $\mathrm{M}$, et al. A case of hypopituitarism due to inflammatory myofibroblastic tumor of the sella turnica. Endocr J. 2008; 55(2): 339 - 44. DOI: 10.1507/endocrj. k07e-047.

11. Gautam S, Ramesh VG, Karthikeyan KV, Krishnakumar M. Intracranial inflammatory pseudotumor presenting as an en plaque mass. Neurol India. 2017; 65(5): 1169 - 70. DOI: 10.4103/neuroindia.NI_395_17.

12. Jeon YK, Chang KH, Suh YL, Jung HW, Park SH. Inflammatory myofibroblastic tumor of the central nervous system: clinicopathological analysis of 10 cases. J Neuropathol Exp Neurol. 2005; 64(3): 254 - 9. DOI: 10.1093/jnen/64.3.254.

13. Greiner C, Rickert CH, Mollman ET, Rieger B, Semik M, Heindel W, et al. Plasma cell granuloma involving the brain and the lung. Acta Neurochir (Wien). 2003; 145(12): 1127 31. DOI: 10.1007/s00701-003-0109-z.

14. Buccoliero AM, Caldarella A, Santucci M, Ammanati F, Mennona P, Taddei A, et al. Plasma cell granuloma-An enigmatic lesion: Description of an extensive intracranial case and review of the literature. Arch Pathol Lab Med. 2003; 127(4): e220 - 23. DOI: 10.1043/0003-9985(2003)127<e220:PCGEL>2.0.CO;2.

15. Coffin CM, Humphrey PA, Dehner LP. Extrapulmonary inflammatory myofibroblastic tumor: A clinical and pathological survey. Semin Diagn Pathol. 1998; 15(2): 85 101.

16. Denis DJ, Elayoubi K, Weil AG, Berthelet F, Bojanowski MW. Inflammatory myofibroblastic tumors of the central nervous system that express anaplastic lymphoma kinase have a high recurrence rate. Surg Neurol Int. 2013; 4: 70. DOI: 10.4103/2152-7806.112614.

17. Tresser N, Rolf C, Cohen M. Plasma cell granulomas of the brain: Pediatric case presentation and review of the literature. Childs Nerv Syst. 1996; 12(1): 52 - 7. DOI: 10.1007/bf00573857.

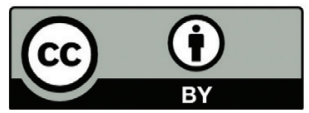

This work is licensed under a Creative Commons Attribution 